The Egyptian Journal of Biochemistry \& Molecular Biology VOL 36(N.1\&2) 65- 78 December. 2018

\title{
LNC RNA HULC AS A NOVEL DIAGNOSTIC AND THERAPEUTIC TARGET IN PREECLAMPSIA
}

\section{Olfat G. Shaker1, Omayma O. Abdelaleem2, Rania H. Mahmoud2, Nada F. Hemeda3, Naglaa A. Ahmed4}

1 Department of Medical Biochemistry and Molecular Biology,

Faculty of Medicine, Cairo University.

Department of 2Medical Biochemistry and Molecular Biology,

Faculty of Medicine, Fayoum University

Department of 3Genetics, Faculty of Agriculture, Fayoum University, Department of 4physiology, Faculty of Medicine, Zagazig University,

Received20 /5 /2018 - Accepted16 / 7 /2018

\begin{abstract}
Background: Preeclampsia is a severe pregnancy-related disease mainly in developing countries. Non-coding RNAs are very important factors in regulating the expression of certain genes and are involved in pathogenesis of numerous diseases. Recently, non coding RNA biomarkers are used as diagnostic tools for different disorders such as PE.

Methods: lnc RNA HULC expression levels was measured in serum collected from 22 patients with $\mathrm{PE}$ and 23 healthy pregnancies, using real-time PCR.

Results: HULC expression was elevated reaching significant levels ( $\mathrm{p}$ $<0.001$ with 2.16 fold change) in patients compared with control group. HULC was markedly increased in both severe and mild preeclamptic subgroups when compared to healthy controls $(p<0.001$ with 1.97 fold change and $\mathrm{p}<0.001$ with 2.16 fold change respectively). ROC curve was assessed, the AUC of lnc RNA HULC was $0.952(95 \%, \mathrm{CI}=0.904-1.000, \mathrm{P}<0.001)$.

Conclusion: lnc RNA HULC may be involved in PE pathogenesis and may be used as potential non-invasive diagnostic biomarker for this disease.
\end{abstract}

Key words: Preeclampsia; lnc RNA HULC.

* Carrespandence Authar (e mail Omayma 0.Abdelaleem@hotmail.com) 


\section{INTRODUCTION}

Preeclampsia (PE), a syndrome among pregnant women especially in developing countries, identified by proteinuria in addition to hypertension following 20 weeks of gestation, affecting $5-7 \%$ of pregnancy disorders worldwide and causes $10 \%$ to $15 \%$ of maternal deaths (MUNAUT et al., 2016).

In spite of progress achieved in this topic, the mechanisms of pathogenesis of PE need to be clarified. Actually many studies have identified that the placenta have a significant role in development of $\mathrm{PE}$, in which poor placentation, shallow invasion, and abnormal angiogenesis, are the main pathological features (BROUGHTON and ROBERTS, 2000). Additionally, many theories related to the pathogenesis of PE have been identified like oxidative stress (NORIS et al., 2004), endothelial dysfunction (GRANGER et al., 2001), inflammatory cytokines (SAFTLAS et al., 2005), genetic and dietary factors (BARTHA et al., 2002) and imbalance between proangiogenic and antiangiogenic factors (RANA et al., 2007).

More efforts are needed to deeply understand the molecular mechanisms of PE. A significant portion of human genome is considered non-protein coding genes (KAWAJI et al., 2011).

LncRNAs are considered as major subclass of noncoding RNAs and are longer than 200 nucleotides. Emerging studies have proposed that lncRNAs which were discovered in the last recent years, are closely associated with the pathogenesis of many diseases, including neurodegenerative diseases (JOHNSON, 2012), cardiovascular disease (LEUNG et al., 2013) and cancer (WANG et al., 2010). Furthermore, many studies recently have indicated that lncRNAs are linked to cell apoptosis and migration (KHAITAN et al., 2011), and may be associated with the behavior of trophoblast cells in PE (ZHANG et al., 2015).

Highly upregulated in liver cancer (HULC) was originally highly expressed in human hepatocellular carcinoma (PANZITT et al., 2007). However, overexpression of HULC has been reported in other cancer types (PENG et al., 2014 and SUN et al., 2015). Recently, few studies indicated that HULC may play a role in cell survival, proliferation and invasion (ZHAO et al., 2014) in addition to its effect on tumor growth (CUI et al., 2015) and angiogenesis (LU et al., 2015). The role of HULC in PE is considered unclear up to now. 
Nowadays, development and diagnosis of PE have become a hard task in clinical research. However, current diagnosis still dependent on the results of urine analysis (proteinuria), blood pressure measurement, and blood tests. Thus, early diagnosis of PE through detection of specific biomarkers has become a major target in current studies. Recently, potential biomarkers have been identified by many studies for accurate and early diagnosis of PE.

The present study aimed at determining the expression levels of HULC in serum of preeclampsia patients and using its clinical values as non-invasive biomarker for diagnosis and prediction of prognosis of preeclampsia.

\section{MATERIALS AND METHODS}

Pregnant women and samples collection: All the serum samples were sequentially collected from outpatient clinics and inpatient departments of Obstetrics and Gynecology, Fayoum University Hospital, Egypt. 22 serum samples were obtained from pregnant women with preeclampsia. Another 23 serum samples were taken from nulliparous women with normal pregnancies which were selected as the controls. The standard diagnostic criteria of preeclampsia were: a systolic blood pressure $>140 \mathrm{mmHg}$ and /or diastolic blood pressure $>90 \mathrm{mmHg}$ at least on two occasions, accompanying with urinary protein level $>0.3 \mathrm{~g}$ in a $24 \mathrm{~h}$ collected urine. Severe PE was defined briefly as blood pressure above 160 $\mathrm{mmHg}$ systolic or diastolic more than $110 \mathrm{mmHg}$ with severe proteinuria following 20 weeks of gestation. The pregnant women with other complications like history of renal disease and/or hypertension, diabetes, smoking, chromosomal abnormalities, alcoholism, and fetal congenital abnormalities were excluded from our study.

This research was revised and approved by the Faculty of Medicine, Fayoum University Ethical Committee. Written informed consent was obtained from all pregnant women before sample collection.

RNA extraction: MiRNeasy extraction kit (Qiagen, Valenica, CA) was used for total RNA extraction using QIAzollysis reagent following the manufacturer's instructions. RNA concentration was detected using NanoDrop2000 (Thermo scientific, USA). 
Reverse transcription reactions: Reverse transcription (RT) was executed on $60 \mathrm{ng}$ of total RNA in a final volume $20 \mu \mathrm{l}$ R reactions using RT2 strand Kit (Qiagen, Valenica, CA) according to the manufacturer's guidelines.

Real-time PCR: Expression levels of serum lnc RNA HULC were determined using GAPDH as internal control using primers and Maxima SYBR Green PCR kit (Thermo, USA) according to the manufacturer's instructions. The primer sequences were as follows: HULC-forward 5'-TCATGATGGAATTGGAGCCTT-3', HULC reverse $5^{\prime}$ - C TCT TCCTGGCTTGCAGATTG-3', and GAPDHforward -5' CCCTTCATTGACCTCAACTA-3', GAPDH-reverse, 5'TGGAAGATGGTGATGGGATT-3'. Real-time PCR was done with the following conditions: $95{ }^{\circ} \mathrm{C}$ for $10 \mathrm{~min}$, followed by 45 cycles at $95{ }^{\circ} \mathrm{C}$ for $15 \mathrm{~s}$ and $60{ }^{\circ} \mathrm{C}$ for $60 \mathrm{~s}$. The fold change of miRNA and lncRNA expression levels were calculated as $2^{-\Delta \Delta \mathrm{Ct}}$ for relative quantification.

Statistical analysis: All the results were defined as mean \pm SD. Results of fold change of lnc RNA HULC was defined as median and inter quartile range (IQR). Comparisons of the groups were examined by Mann-Whitney U test for non-parametric data. Receiver operating characteristic (ROC) curve was achieved with using area under curve (AUC) to assess the best cutoff value of HULC to be used as biomarker for diagnosis of preeclampsia. Data indicated a statistically significant difference at values of $\mathrm{P}<0.05$.

\section{RESULTS}

Clinical and demographic characteristics of case-control study: The main clinical and demographic findings which were obtained from all subjects who participated in the study (22 pregnant women who had $\mathrm{PE}$ and 23 healthy pregnant females) are demonstrated in Table 1 . The mean ages \pm SD of the pregnant women with PE were $31.05 \pm 6.90$ years and $29.83 \pm 7.30$ years for healthy control group. The differences between the preeclamptic patients and the normal pregnant female as regards systolic blood pressure, diastolic blood pressure and mean arterial pressure (MAP) were significantly high ( $\mathrm{p}<0.0001$ for each of them). Additionally there were significant variations in serum levels of AST ( $\mathrm{p}=0.015)$, creatinine ( $\mathrm{p}=0.012), 2 \mathrm{~h}$ PP blood glucose, PT, and PC $(\mathrm{p}<0.0001)$. All other parameters including maternal age, body 
mass index, gestational age, Albumin, ALP and FBS were not statistically different in cases versus controls.

Expression of lnc RNA HULC in preeclampsia and normal pregnant women: To investigate the expression levels of lnc RNA HULC in PE, we analyzed lnc RNA HULC level in the serum from women with PE and healthy pregnant women. Fold change method was used in our study and the relative expression level of lnc RNA HULC in the healthy group were set as 1 (TORAIH et al., 2016).

The expression level (fold change) of lnc RNA HULC in the serum was compared between the two groups. The results showed that the fold change of HULC in preeclamptic patients was upregulated significantly compared with the normal pregnant women, $(p<0.001$ with 2.16 fold change).

We stratified the preeclamptic patients according to the severity of PE into mild and severe preeclamptic patients and compared lnc RNA HULC expression to that of the control. Inc RNA HULC was markedly increased in both severe and mild preeclamptic subgroups when comparing to healthy controls $(\mathrm{p}<0.001$ with 1.97 fold change and $\mathrm{p}<0.001$ with 2.16 fold change, respectively) Figure 1

Correlation between the clinical data and the expression level of Inc RNA HULC

To further elucidate the significance of lnc RNA HULC in preeclampsia, we calculated the correlation of lnc RNA HULC expression with the clinical data of the study subjects. No association of lnc RNA HULC was found with the clinical data (data not shown).

Diagnostic performance of serum lnc RNA HULC for preeclampsia patients: In order to study the diagnostic accuracy of lnc RNA HULC as biomarker for PE, a ROC curve was calculated (Figure 2 and Table 2 ). The value of the area under the ROC curve (AUC) of (95\% confidence interval $(\mathrm{CI})=0.904-1.000, \mathrm{P}<0.001)$.

These results demonstrated that lnc RNA HULC may be promising biomarker for diagnosis of PE. 
Table 1: Clinical data and laboratory features.

Data expressed as Mean \pm SD.

\begin{tabular}{|c|c|c|c|}
\hline Variables & $\begin{array}{c}\text { Healthy } \\
\text { Pregnancies } \\
(\mathbf{n}=23)\end{array}$ & $\begin{array}{r}\begin{array}{c}\text { Preeclampsia } \\
\text { Pregnancies } \\
(n=22)\end{array}\end{array}$ & P value \\
\hline Age, year & $29.83 \pm 7.30$ & $31.05 \pm 6.90$ & 0.568 \\
\hline $\begin{array}{l}\text { body mass index, } \\
\mathrm{kg} / \mathrm{m} 2\end{array}$ & $31.04 \pm 4.30$ & $28.77 \pm 3.48$ & 0.058 \\
\hline Systolic BP, mm Hg & $114.78 \pm 14.02$ & $157.05 \pm 17.02$ & $<0.001$ \\
\hline diastolic $\mathrm{BP}, \mathrm{mm} \mathrm{Hg}$ & $71.74 \pm 8.20$ & $105.00 \pm 10.00$ & $<0.001$ \\
\hline MAP, $\mathrm{mm} \mathrm{Hg}$ & $93.26 \pm 9.43$ & $131.23 \pm 12.35$ & $<0.001$ \\
\hline Gestational weeks & $37.17 \pm 1.48$ & $36.39 \pm 1.84$ & 0.126 \\
\hline AST,(U/L) & $19.35 \pm 9.86$ & $40.36 \pm 54.35$ & 0.015 \\
\hline Albumin,(g/dl) & $3.30 \pm 0.38$ & $3.01 \pm 0.39$ & 0.164 \\
\hline ALP,(U/L) & $73.13 \pm 2.32$ & $73.95 \pm 2.77$ & 0.084 \\
\hline $\begin{array}{ll}\text { Serum } \\
(\mathrm{mg} / \mathrm{dl})\end{array} \quad$ creatinine, & $0.64 \pm 0.17$ & $0.81 \pm 0.33$ & .012 \\
\hline FBS, (mg/dl) & $77.74 \pm 11.98$ & $80.41 \pm 13.49$ & 0.058 \\
\hline $\begin{array}{|lccc|}\begin{array}{l}\text { 2h } \\
(\mathrm{mg} / \mathrm{dl})\end{array} & \text { bl. } & \text { GLU, } \\
\end{array}$ & $113.22 \pm 16.70$ & $118.55 \pm 17.32$ & $<0.001$ \\
\hline PT(seconds) & $12.43 \pm 1.12$ & $12.41 \pm 0.73$ & $<0.001$ \\
\hline PC & $116.57 \pm 15.30$ & $104.64 \pm 27.57$ & $<0.001$ \\
\hline (IUGR), Yes & $16(72.7 \%)$ & $3(13.0 \%)$ & \multirow{2}{*}{$<0.001$} \\
\hline (IUGR), No & $6(27.3 \%)$ & $20(91.3 \%)$ & \\
\hline Albumin in urine & & & \\
\hline $\begin{array}{l}1+ \\
2+ \\
3+ \\
4+\end{array}$ & \begin{tabular}{|l}
$5(22.7 \%)$ \\
$10(45.5 \%)$ \\
$3(13.6 \%)$ \\
$4(18.2 \%)$
\end{tabular} & $\begin{array}{l}0(0.0 \%) \\
0(0.0 \%) \\
0(0.0 \%) \\
0(0.0 \%)\end{array}$ & $<0.001$ \\
\hline
\end{tabular}

$\mathrm{BP}$, blood pressure; MAP, mean arterial pressure; FBS, fasting blood sugar; $2 \mathrm{~h}$ PP bl. GLU, 2 hour post prandial blood glucose; PT, prothrombin time; ; PC, prothrombin concentration; IUGR, intra uterine growth retardation. 
Table 2: Predictive power, in diagnosis of preeclampsia, by lnc RNA HULC.

\begin{tabular}{|c|c|c|c|c|c|c|}
\hline Variable & $\begin{array}{c}\text { AUC } \\
(\mathbf{9 5 \%} \text { CI })\end{array}$ & P-value & $\begin{array}{c}\text { Cut off } \\
\text { point }\end{array}$ & Sensitivity Specificity & $\begin{array}{c}\text { Total } \\
\text { accuracy }\end{array}$ \\
\hline HULC & $\begin{array}{c}0.952 \\
(0.904-1.00)\end{array}$ & $<0.0001$ & 1.035 & $95.2 \%$ & $100.00 \%$ & 97.7 \\
\hline
\end{tabular}

AUC: area under the curve; CI: confidence interval.

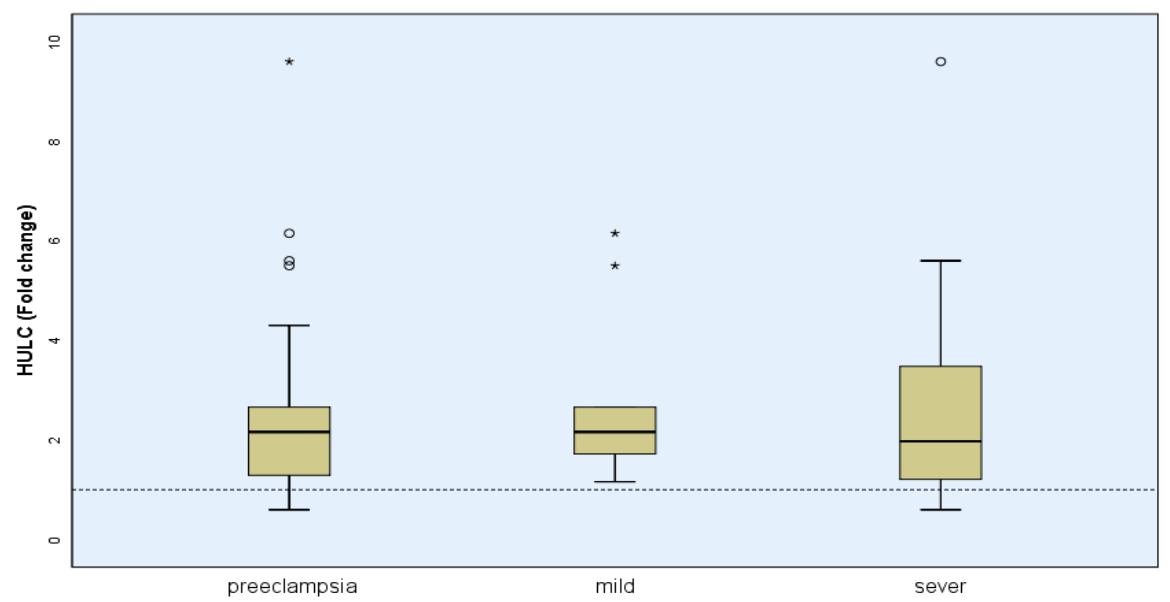

Figure 1. Lnc RNA HULC expression levels in PE pregnancies versus healthy pregnancies (box plot representation). The levels of HULC was elevated significantly in PE pregnancies, mild preeclampsia and severe preeclampsia subgroups relative to healthy pregnant females $(\mathrm{p}<0.001$, each). The horizontal dotted line represents the expression level of the control group. 


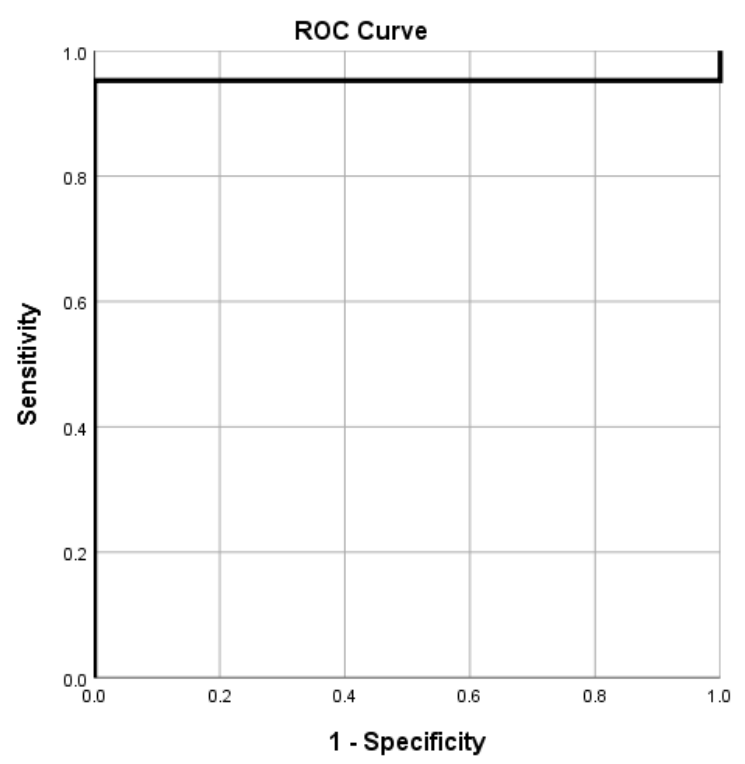

Figure 2. ROC curve analysis for lnc RNA HULC between the cases of PE pregnancies and healthy pregnancies. The AUC between 0.5 and 1 was considered having diagnostic significance.

\section{DISCUSSION}

$\mathrm{PE}$ is a multisystem pregnancy disorder affecting about 10 million women worldwide (DULEY, 2009). It is significantly associated with pregnancy-related fetal and maternal morbidity and mortality (KHOWAJA et al., 2015).

Some factors such as superficial placentation, massive maternal inflammation, endothelial dysfunction, hypoxia of placenta and poor angiogenesis, have been suggested as key etiological findings. However, determining the exact etiology of PE has been proved to be a hard task (SERRANO, 2006). So, it is critical to demonstrate how the gene regulatory mechanisms, which may act as a tool to determine therapeutic targets for prevention and early diagnosis of PE.

In recent years, non-protein coding RNAs which represent more than $90 \%$ of the human genome transcriptional products, have taken more interest as they have appeared as a new class of important regulators of gene expression (SERRANO, 2006). Among these, miRNAs which have considered as important factors contributing to the development and progression of PE (SALOMON et al., 2017). Additionally, 
lncRNAs, novel molecules of noncoding genes, have been certified as crucial member of these biological RNAs. However, the biological roles and molecular mechanisms of lncRNAs related to the pathogenesis of PE are not yet well demonstrated (ZOU et al., 2013).

Currently, it was detected that non coding RNAs may serve as novel potential biomarkers for early diagnosis, prognosis prediction, and effective therapeutic targets of numerous diseases (CUI et al., 2014 and LIU et al., 2015).

In this study, we found for the first time a higher expression levels of lnc RNA HULC in serum of preeclamptic patients than the normal pregnancies ( $\mathrm{p}<0.001$ with 2.16 fold change). HULC was significantly increased in each of severe and mild preeclamptic subgroups when comparing to normal controls $(\mathrm{p}<0.001$ with 1.97 fold change and $\mathrm{p}<0.001$ with 2.16 fold change, respectively).

Lnc RNA HULC has been involved in various pathophysiological pathways, such as oxidative stress, cancer, and apoptosis. It was proved that HULC could activate the secretion of IL-6 in cholangiocarcinoma. As inflammatory genes including IL-6 and CXCR4 are target for HULC (WANG et al., 2016).

It was detected that cytokines could be included in the pathogenesis of PE (CHAN et al., 2002). Interleukin-6 (IL-6) and TNFa are pro inflammatory cytokines having injurious and adverse effects on pregnancy. IL-6 and TNF $\alpha$ are secreted mainly by neutrophils, macrophages and granulocytes and are considered as main regulators of acute phase response. Neutrophil cells activation and overproduction of cytokines by the placenta in response to local ischemia are most probably playing a vital role in the presence of damaged endothelium associated with PE (CLARK and BOSWELL, 1998).

In addition, HULC was upregulated by oxidative stress (WANG et al., 2016). The oxygen tension at the feto-maternal interface was much lower than healthy pregnancies due to the reconstruction of maternal blood vessels by trophoblasts (LUO et al., 2016) aggravating the hypoxic condition at the feto-maternal interface which cause oxidative stress (LUO et al., 2014). It was proved that HULC may regulate the inflammatory factors after stimulating oxidative stress (WANG et al., 2016). 
In placentas of preeclamptic patients, lipid peroxidation and damaged protein molecules are significantly increased when compared to nonpathological placentas (Vanderlelie et al., 2005). This could be due to an increase of oxidative stress (Shaker et al., 2013 and Can et al., 2014), or a decrease of activities of antioxidant enzymes like superoxide dismutase (Vanderlelie et al., 2005). Oxidative stress can also stimulate the accumulation of advanced oxidation protein products, which could have an adverse effect on trophoblast cells and lead to development of PE (Huang et al., 2013).

ROC analysis is a widely accepted method for analyzing and comparing the diagnostic accuracy of body fluid tests. By performing ROC analysis, we found that HULC had the diagnostic power with an AUC of $0.952(95 \%, \mathrm{CI} .861-1.000, \mathrm{P}<0.001)$ which is observed to be higher than of the AUC of miR-155 (which was measured in our study and was found to be upregulated). AUC of miR-155 was 0.667 (95\% CI=0.465-0.868, $\mathrm{P}=0.059$ ). Our results of upregulated miR-155 were consistent with many studies (LI et al., 2014 and CHENG et al., 2011).

In conclusion, we identified that lnc RNA HULC had the potential to be novel diagnostic biomarker and it may be utilized as therapeutic target in treatment of PE.

Author Contributions: Olfat G. Shaker, Omayma O. Abdelaleem, Rania H. Mahmoud performed the biochemical assays, Nada F. Hemeda, Naglaa A. Ahmed interpreted the data. All authors read and approved the final manuscript.

\section{REFERENCES}

\section{Bartha JL, Romero-Carmona R, Torrejon-Cardoso R, Comino-}

Delgado R. (2002): Insulin, insulin-like growth factor-1, and insulin resistance inwomen with pregnancy-induced hypertension. Am J Obstet Gynecol. 187, 735-740.

Broughton Pipkin F, Roberts JM. (2000): Hypertension in pregnancy. J. Hum Hypertens. 14, 705-24.

Can M, Guven B, Bektas S, et al. (2014): Oxidative stress and apoptosis in preeclampsia. Tissue Cell. 46, 477-481.

Chan JC, Cheung JC, Stehouwer CD, Emeis JJ, Tong PC, et al.(2002): The central roles of obesity-associated dyslipidemia, endothelial activation and cytokines in the Metabolic Syndrome - an 
analysis by structural equation modelling. Int $\mathrm{J}$ ObesRelatMetabDisord.26, 994-1008.

Cheng W, Liu T, Jiang F, Liu C, Zhao X, et al. (2011): microRNA155 regulates angiotensin II type 1 receptor expression in umbilical vein endothelial cells from severely pre-eclamptic pregnant women.Int J Mol Med. 27, 393-399.

Clark P, Boswell F, Greer IA (1998): The neutrophil and preeclampsia. Semin Reprod Endocrinol. 16, 57-64.

Cui H, Xie N, Tan Z, Banerjee S, Thannickal VJ, et al. (2014): The human long noncoding RNA lnc-IL7R regulates the inflammatory response.Eur J Immunol. 44, 2085-2095.

Cui M, Xiao Z, Wang Y, et al. (2015): Long noncoding RNA HULC modulates abnormal lipid metabolism in hepatoma cells through miR9-mediated RXRA signaling pathway. Cancer Res. 75, 846-857.

Duley L. (2009): The global impact of pre-eclampsia and eclampsia. SeminPerinatol.33, 130-137.

Granger JP, Alexander BT, Llinas MT, Bennett WA, Khalil RA (2001): Pathophysiology of hypertension during preeclampsia linking placentalischemia with endothelial dysfunction. Hypertension 38, 718722.

Huang QT, Wang SS, Zhang M, et al (2013): Advanced oxidation protein products enhances soluble fms-like tyrosine kinase1expressionin trophoblasts: Apossible link between oxidative stress and preeclampsia. Placenta 2013, 34, 949-952.

Johnson R. (2012): Long non-coding RNAs in Huntington0s disease neurodegeneration. In: Neurobiol Dis. 46, 245-254.

Kawaji H, Severin J, Lizio M, Forrest AR, van Nimwegen E, et al. (2011): Update of the FANTOM web resource: From mammalian transcriptionallandscape to its dynamic regulation. Nucleic Acids Res. 39, 856-860.

Khaitan D, Dinger ME, Mazar J, Crawford J, Smith MA et al. (2011): Themelanoma-upregulated long noncoding RNA SPRY4-IT1 modulatesapoptosis and invasion. Cancer Res. 71, 3852-3862.

Khowaja AR, Mitton C, Bryan S, Magee LA, Bhutta ZA, et al. (2015): Economic evaluation of Community Level Interventions for Pre-eclampsia (CLIP) in South Asian and African countries: a study protocol. Implement Sci. 10, 76. . 
Leung A, Trac C, Jin W, Lanting L, Akbany A, et al. (2013): Novel long noncoding RNAs are regulated by angiotensinII in vascular smooth muscle cells. Circ Res. 113, 266-278.

Li X, Li C, Dong X, Gou W. (2014): MicroRNA-155 inhibits migration of trophoblast cells and contributes to the pathogenesis of severe preeclampsia by regulating endothelial nitric oxide synthase. Mol Med Rep. 10, 550-554.

Liu Y, Luo F, Xu Y, Wang B, Zhao Y, et al. (2015): Epithelialmesenchymal transition and cancer stem cells, mediated by a long non-coding RNA, HOTAIR, are involved in cell malignant transformation induced by cigarette smoke extract. Toxicol Appl Pharmacol. 282, 9-19.

Lu Z, Xiao Z, Liu F, et al. (2015): Long non-coding RNA HULC promotes tumor angiogenesis in liver cancer by up-regulating sphingosine kinase 1 (SPHK1). Oncotarget 7, 241-254.

Luo R, Shao X, Xu P, Liu Y, Wang Y, et al. (2014): MicroRNA210 contributes topreeclampsia by downregulating potassium channel modulatory factor 1 . Hypertension 64, 839-845.

Luo R, Wang Y, Xu P, Cao G, Zhao Y, et al. (2016): Hypoxiainducible miR210 contributes to preeclampsia via targeting thrombospondin type I domain containing 7A. Sci Rep. 6, 19588.

Munaut C, Tebache L, Blacher S, Noël A, Nisolle M, et al. (2016): Dysregulated circulating miRNAs in preeclampsia. Biomed Rep. 5(6), 686-692

Noris M, Todeschini M, Cassis P, Pasta F, Cappellini A et al. (2004): Largininedepletion in preeclampsia orients nitric oxide synthase towardoxidant species. Hypertension 43, 614-622.

Panzitt K, Tschernatsch MM, Guelly C, et al. (2007): Characterization of HULC, a novel gene with striking up-regulation in hepatocellular carcinoma, as noncoding RNA. Gastroenterology 132, 330-342.

Peng W, Gao W, Feng J.(2014): Long noncoding RNA HULC is a novel biomarker of poor prognosis in patients with pancreatic cancer. Med Oncol. 31, 346.

Rana S, Karumanchi SA, Levine RJ, Venkatesha S, Rauh-Hain JA et al. (2007): Sequential changes in antiangiogenic factors in earlypregnancy and risk of developing preeclampsia. Hypertension 50, 137-142. 
Saftlas AF, Beydoun H, Triche E. (2005): Immunogenetic determinants of preeclampsia and related pregnancy disorders: a systematic review. Obstet Gynecol. 106, 162-172.

Salomon C, Guanzon D, Scholz-Romero K, Longo S, Correa P, et al. (2017): Placental exosomes as early biomarker of preeclampsia potential role of exosomal microRNAs across gestation. In: J. ClinEndocrinolMetab.102, 3182-3194.

Serrano NC. (2006): Immunology and genetic of preeclampsia. ClinDevImunol. 13, 197-201.

Shaker OG, Sadik NA (2013): Pathogenesis of preeclampsia: Implications of apoptotic markers and oxidative stress. Hum. Exp. Toxicol. 32, 1170-1178.

Sun XH, Yang LB, Geng XL, et al. (2015): Increased expression of lncRNA HULC indicates a poor prognosis and promotes cell metastasis in osteosarcoma. Int J. Clin Exp Pathol. 8, 2994-3000.

Toraih EA, Fawzy MS, Mohammed EA, Hussein MH, El-Labban MM (2016): MicroRNA-196a2 Biomarker and Targetome Network Analysis in Solid Tumors. Mol Diagn Ther. 20(6), 559-577.

Vanderlelie J, Venardos K, Clifton VL, et al. (2005): Increased biological oxidation and reduced anti-oxidant enzyme activity in preeclamptic placentae. Placenta. 26, 53-58.

Wang J, Liu X, Wu H, Ni P, Gu Z, et al. (2010): CREB up-regulates long non-coding RNA, HULC expression through interaction with microRNA-372 in liver cancer. Nucleic Acids Res. 38, 5366-5383.

Wang WT, Ye H, Wei P, Han B, He B, et al. (2016): Lnc RNAs H19 and HULC, activated by oxidative stress, promote cell migration and invasion in cholangiocarcinoma through a ceRNA manner. $J$ Hematol Oncol. 9, 117.

Zhang Y, Zou Y, Wang W, Zuo Q, Jiang Z, et al.(2015): DownRegulated Long Non-Coding RNA MEG3 and its Effect on Promoting Apoptosis and Suppressing Migration of TrophoblastCells. J Cell Biochem. 116,542-550.

Zhao Y, Guo Q, Chen J, et al. (2014): Role of long non-coding RNA HULC in cell proliferation, apoptosis and tumor metastasis of gastric cancer: a clinical and in vitro investigation. Oncol Rep. 31, 358-364.

Zou Y, Jiang Z, Yu X, Sun M, Zhang Y, et al. (2013): Upregulation of Long Noncoding RNA SPRY4-IT1 Modulates 
Proliferation, Migration, Apoptosis, and Network Formation in Trophoblast Cells HTR-8SV/neo. PLoS One 8, e79598.

\section{الملخص العربي}

استخدام ر.ن.أ. غير المشفرة Lnc RNA HULC كهذف تثخيصي وعلاجي في تسمم الحمل

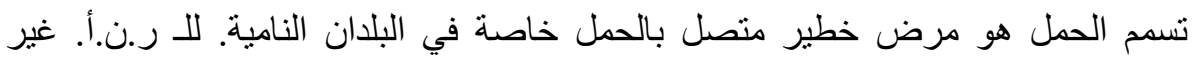

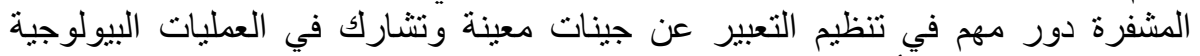

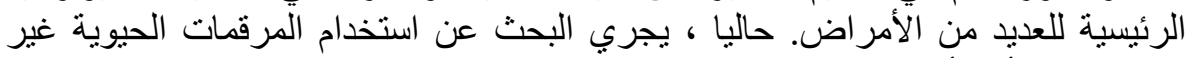

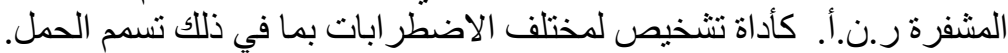

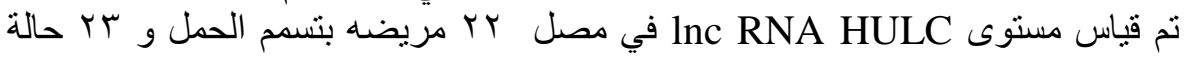

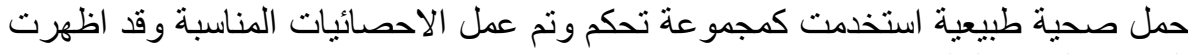

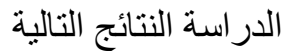

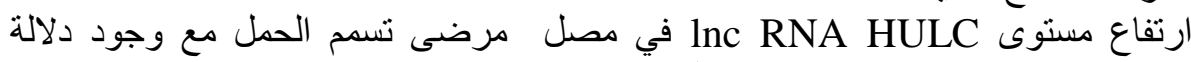
احصائية مرتفعة بينها وبين مجمو عة التحكم.

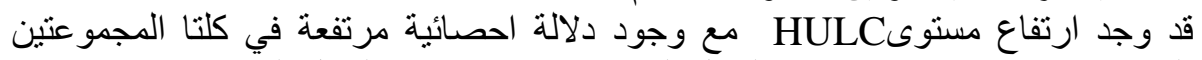

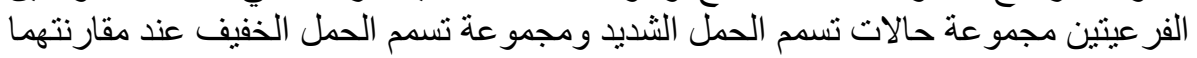
بمجمو عة التحكم. ومن هنا نستخلص انه قد تشارك Lnc RNA HULC في إمراضية تسمم الحمل ويمكن استخدامها كمؤشرات حيوية محتملة لهذا المرض. فئر 